\title{
Community-based groundwater and ecosystem restoration in semi- arid north Rajasthan (3): evidence from remote sensing
}

Thomas Davies, University of the West of England (UWE), Coldharbour Lane, Frenchay Campus, Bristol BS16 1QY, UK.

Dr Mark Everard, University of the West of England (UWE), Coldharbour Lane, Frenchay Campus, Bristol BS16 1QY, UK (Corresponding author:

mark.everard@uwe.ac.uk, +44-(0)-7747-120019).

Michael Horswell, University of the West of England (UWE), Coldharbour Lane, Frenchay Campus, Bristol BS16 1QY, UK.

\begin{abstract}
Community-based measures recharging groundwater in semi-arid India has historically underpinned rural socio-ecological resilience, though are declining through technological, policy and other changes. Nevertheless, exemplars of community action are achieving catchment regeneration, including in Alwar District (Rajasthan) since the mid-1980s. This study analysed satellite remote sensing (RS) data to detect trends in groundwater and linked ecosystem services. Data from Landsat satellite missions offered a long time series and free access, though data gaps in the LandSat archive prior to 1997 limited time series analysis. ISODATA (Iterative Self Organising Data Analysis Technique) was used to analyse land cover trends, detecting increasing vegetation cover but not river rejuvenation due to limited spatial and spectral resolution. Analyses of NDVI (Normalised Difference Vegetation Index) and MSI (Moisture Stress Index) were used to assess change in vegetation cover, vigour and moisture stress over time. Analytical outputs were equivocal, although inter-annual fluctuations were observed to follow antecedent rainfall as vegetation responded to rising soil moisture and groundwater. Despite these equivocal conclusions, the research strongly suggests that analysis of RS data with improved resolution can provide surrogate indicators of change in groundwater and associated ecosystem services, supporting formulation of flexible policies incorporating local action to regenerate socio-ecological systems.
\end{abstract}

\section{Keywords}

Ecosystem services, community-based management, water, regeneration, cultural, aquatic ecosystems, remote sensing

\section{Research highlights}

- Remote sensing enables examination of trends in vegetation as a surrogate for service provision

- Resolution of current data produces equivocal results, but the analytical methods offer potential 
- Improved imagery and analytical methods will enhance resolution of trends across landscapes

- Landscape-scale analysis may highlight the important role of local management for broader goals

\section{Introduction}

Water security is and will remain a pervasive challenge in the face of a rising global population and a changing climate, particularly across the developing world. Over 1.7 billion people globally live in river basins where overuse of water contributes to depletion at a rate that exceeds natural recharge; were this trend to continue, twothirds of the global population will be living in water-stressed conditions by 2025 (USAID, 2015; United Nations, 2015; Chenworth, 2008). Water is consequently an underpinning resource for a number of the UN Sustainable Development Goals (United Nations, 2015), both in terms of indirect access to clean, safe water and in its roles in sanitation, health, food and energy production and other human needs. Groundwater has played a significant role in increasing India's agricultural output and progress with water security, supporting $62 \%$ of India's total irrigated agricultural area and over $80 \%$ of rural and urban water supplies in 2009-2010 (Central Water Commission, 2013; Kidwell, 2015). Overexploitation of groundwater, particularly for irrigation, has resulted in substantial, widespread depletion of water tables and also increased the vulnerability of groundwater to pollution and increasing salinity and other forms of contamination (Postel, 2015). However, the Water Resources Group (2009) predicts that the national supply will fall $50 \%$ below demand by 2030 , deepening what is already recognised as a water security crisis. Aside from its direct uses, water is a vector of a wide range of ecosystem services upon which ecosystem and human wellbeing depend. Understanding groundwater trends is crucial if more sustainable management is to be achieved, particularly in arid and semi-arid areas where water is often a principal limiting factor to development.

In the face of declining groundwater trends across India, there have been a number of localised successes in regeneration of ecosystems and closely linked socioeconomic fortunes. One such regional example has been achieved by communitybased activities regenerating groundwater and the wider socio-ecological system in a number of adjacent catchments in Alwar District, Rajasthan, north India (Everard, 2015 and 2016). Assessing groundwater trends and the efficacy of local measures to regenerate it over wide geographical areas is challenging. For this reason, cheaper and broader-scale methods must be found to inform more sustainable approaches to the management of water and ecosystems, with detection of groundwater by direct or surrogate means a proxy for a broader set of linked ecosystem services vital for human development and ecosystem resilience.

The potential of remote sensing (RS) for groundwater monitoring has been explored extensively over the past thirty or so years (Heilman and Moore, 1982; Meijerink, 1996; Edet et al., 1998; Rosenberry, 2000; Jin et al., 2007; Lv et al., 2012; Chinnasamy et al., 2015) and reviewed by Becker (2006) and Pérez Hoyos (2016). Becker's (2006) observation regarding the key constraint on RS application in groundwater studies remains true today: current space and airborne sensors have little capacity to penetrate the ground surface. Consequently, RS approaches to 
groundwater monitoring have focussed principally on the use of multispectral observations of the earth surface, relying on proxy indicators of groundwater such as vegetation or thermal fluxes. As a more recent alternative approach, the launch of the Gravity Recovery And Climate Experiment (GRACE) satellite mission in 2002 enables detection of changes in the gravitational field of the Earth, which is affected by the presence of large volumes of water.

Chinnasamy et al. (2015) used GRACE data to investigate groundwater storage and recharge within different agroclimatic zones in Rajasthan, India. Their methodology proved useful for detecting large-scale trends, but found trends were highly dependent on antecedent moisture conditions. Jin et al. (2007) used Normalized Difference Vegetation Index (NDVI) data at 250m spatial resolution from the Modis (Moderate Resolution Imaging Spectroradiometer) satellite mission correlated with groundwater depth interpolated from a series of observation wells to assess the relationship between vegetation growth and groundwater in the arid Yinchuan Plain in China. Their findings suggest a relationship exists in areas with relatively shallow groundwater (NDVI values of 0.4 and above), suggesting that green vegetation characterised areas where depth to groundwater was less than $6.2 \mathrm{~m}$. The highest NDVI values were associated with a groundwater depth of $3.5 \mathrm{~m}$. In the arid Ejina area, Jin et al. (2011) found that NDVI peaked at groundwater depths of $3.4 \mathrm{~m}$. More recently, Lv et al. (2012), using LandSat TM data (30m resolution), found that higher NDVI values in the semi-arid Hailutu River catchment were highly dependent on groundwater availability when groundwater depth was less than $10 \mathrm{~m}$. These findings suggest a stronger relationship between vegetation growth (measured using the NDVI) and a shallower water table in arid areas, than in semi-arid areas. All these studies highlighted concerns about the influence of local factors and contaminating variables, such as the local species composition influencing NDVI values, or climate (e.g. antecedent moisture conditions), or local soil characteristics and topography.

Becker (2006) notes that surface expressions of groundwater are usually identifiable through vegetation, either as stress in waterlogged soils or as vigour in waterresistant species. In arid areas in particular, where water is the main limiting factor controlling plant growth such as our study area, vegetation can provide important clues regarding the occurrence of groundwater. However, Becker (2000) also notes that it is often difficult to separate such expressions of groundwater from seasonal or event-driven surface water. The review by Pérez Hoyos et al. (2016) confirms a strong coupling between rainfall, water table depth, vegetation and soil. Toth's (1963) conceptual model of groundwater flow has implications: if the adopted RS approach is reliant on surface expressions of groundwater or groundwater proxies, characteristic of systems with relative shallow groundwater flow, then the shallower the groundwater flow, the smaller the surface expressions of the flow are likely to be, and the higher the required resolution of the RS imagery becomes.

Resolution of satellite imagery can be considered in three realms: spatial resolution; spectral resolution; and temporal resolution (see Box 1). There is an inevitable tension between the resolution of the sensors and the scale of the phenomena being investigated. For example, GRACE, with a ground resolution of approximately $300 \mathrm{~km}$ is of little use in local or sub-regional projects, while Landsat with a spatial resolution of $30 \mathrm{~m}$ is appropriate for vegetation studies, however, the $60 \mathrm{~m}$ resolution 
of the thermal bands is probably too coarse to resolve local surface expressions of groundwater such as springs. The use of any higher resolution imagery sources (such as QuickBird or IKONOS) is generally constrained by cost. The implication of the above is that, in a cost-constrained context with a local focus, the use of vegetation fluxes as a proxy indicator of groundwater fluxes is a defensible, possibly inevitable, choice.

\section{Box 1: Spatial, spectral and temporal resolution of satellite imagery}

Spatial resolution determines the detail discernible, generally defined by the smallest feature that can be detected. Remotely sensed images comprise a matrix of pixels (the smallest units of an image, normally square, representing a specific area of the image). Spatial resolution is related to pixel density on the sensor as well as the distance between the target being imaged and the sensor platform (satellite altitude). The spatial resolution of passive sensors, as used for example on the Landsat missions that provided images used in this study, depends primarily on their Instantaneous Field of View (IFoV: the angular cone of visibility of the sensor). Each recording cell on the sensor detects average brightness across all sensed features within the cell, so the relative brightness of even small features can dominate what is detected within a particular cell. Satellite images are divided into three classifications of spatial resolution: low resolution $\left(30-1,000 \mathrm{~m}^{2}\right.$ for each pixel); medium resolution $\left(4-30 \mathrm{~m}^{2}\right.$ per pixels); and high resolution images $\left(0.6-4 \mathrm{~m}^{2}\right.$ pixel size) (NRCAN, 2012; Satellite Imaging Corporation, 2015).

Spectral resolution describes the ability of a sensor to define fine wavelength intervals. Broad classes of sensed terrains, such as water and vegetation, can usually be separated using very broad wavelength ranges (such as the visible and Near-IR) though discerning more similar Earth surface types requires comparison of much finer wavelengths. Most satellite remote sensing systems are multispectral, recording electromagnetic energy over several separate wavelength bands at different spectral resolutions.

Temporal resolution relates to the collection of imagery of the same area of Earth's surface at different periods of time. The temporal resolution of a sensor depends on a variety of factors, including the satellite/sensor capability, swath overlap (a swath is the width of images sensed, wide swathes allow more rapid revisit and greater overlap whereas narrow swathes typically allow for higher spatial resolution but revisit time is less frequent) and latitude. Temporal resolution is an important consideration when persistent cloud cover obscures the view of the Earth's surface, potentially obscuring short-lived phenomena (floods, oil slicks, etc.) (NCRAN, 2014).

This study interpreted satellite remote sensing imagery as evidence to test trends in groundwater and ecosystem regeneration in Alwar District, Rajasthan, reported by Everard (2015). We chose to use a time series of Landsat5 TM and Landsat8 OLI data because of the catchment scale of the project, the available record length of data, its suitability for vegetation studies (due to its spectral resolution) and the fact that access to the data is free. 


\section{The case study area}

Rajasthan is India's largest state, occupying $10 \%$ of India's land area but only $1 \%$ its surface water resources. $60 \%$ of the state is arid, with the remaining $40 \%$ semi-arid (Jayanti, 2009). Most of western Rajasthan falls under the 'Sub-tropical arid (desert)' climate type in the Köppen climate classification (Köppen and Wegener, 1924) whilst the region east of the Aravalli range is 'Sub-tropical humid (wet)' experiencing dry winters. $90 \%$ of Rajasthan's annual rainfall, which is often erratic and localised, occurs in the monsoon months of July to September (Jayanti, 2009). In Rajasthan, as for much of India, the strongly seasonal rainfall allied with a generally hot climate results in a heavy reliance on groundwater for domestic, industrial and agricultural purposes.

Ninety-two percent of India's extractions of groundwater is used for irrigation (Central Ground Water Board, 2006). Everard (2015) reviews the substantial extent to which groundwater supports India's demand for water. Following India's independence, there has been a pronounced trend towards centralisation of control of water management to state and national levels. India's constitution states that surface water is a government-owned resource and only state governments are empowered to enact water management laws, and to control and regulate groundwater exploitation. Responsibilities for management of water is divided between a range of government institutions at national and state levels (see Table 1), some of which have competing or conflicting priorities, resulting in a fragmented approach to water management that exacerbates water stress principally by disempowering community management (Singh and Singh, 2002). Major reductions in local groundwater recharge are compounded by widespread energisation (diesel and electric pumps) of water extraction from ever-deeper wells and tube wells, exacerbating groundwater depletion and frequently contributing to societal inequities, vulnerability and poverty.

Table 1: National and State control of water management

\begin{tabular}{|l|l|}
\hline $\begin{array}{l}\text { Administrative level } \\
\text { in India }\end{array}$ & Institutions responsible for water management \\
\hline National level & $\begin{array}{l}\text { Three primary institutions are involved in the management of water } \\
\text { resources: } \\
\text { (1) The Ministry of Water Resources (MWR) that has responsibility for } \\
\text { enacting policy guidelines, development programmes and regulation of } \\
\text { national water resources; }\end{array}$ \\
$\begin{array}{l}\text { (2) The Planning Commission that allocates financial resources to the } \\
\text { states and the MWR to support water resource development programmes; } \\
\text { and }\end{array}$ & $\begin{array}{l}\text { (3) the Ministry of Agriculture that promotes irrigated agriculture } \\
\text { In addition to these three primary institutions, the Central Groundwater } \\
\text { Authority was established in } 1996 \text { to control and regulate groundwater } \\
\text { development }\end{array}$ \\
\hline
\end{tabular}


Everard (2015) reviews how these factors, exacerbated by population growth and climatic change, have combined to remove water management responsibilities from local control in Rajasthan and elsewhere in India with a range of significant adverse socio-ecological consequences. There has been widespread abandonment of locally adapted community management institutions and rainwater-harvesting techniques reflecting historic adaptation to local climatic conditions. Declining ecosystem vitality from greater water stress, including the extent of forest cover, lies at the heart of a cycle of linked ecological and social degradation resulting in rural hydrological poverty. This is manifest through the declining viability of stock and crop production, fuel wood availability, and increased drudgery for women who have traditional roles in gathering water, fuel wood and fodder. Village abandonment, particularly by the young seeking greater opportunities in burgeoning cities, has been observed across Rajasthan as also other drier areas of India experiencing similar cycles of degradation of the linked socio-ecological system.

To counter this pervasive degenerative cycle, a programme led by the NGO Tarun Bharat Sangh (TBS) has been active since 1985, restoring village-scale community management of water (also reviewed by Rathore, 2003, Sinha et al., 2013, and Everard, 2015). Central to the TBS approach has been restoration of a diversity of locally appropriate water harvesting structures (WHSs) and the community institutions necessary to initiate, build and maintain them as well as to govern water use on an equitable and sustainable basis. This builds upon India's long tradition of water harvesting as an adaptation to local climatic conditions. These diverse WHSs go by a range of regional names, including as a subset of examples: Baudis particularly in Himachal Pradesh state; Dongs in Assam; Virdas and jheels in the grasslands of Gujarat; Zabo in Nagaland; Tanks or eris across South India; and Ooranis in south Travancore (George et al., 2015). However, they are commonly referred to in Rajasthan as 'johadi' (singular: 'johad'). WHSs serve to intercept or slow overland flows during monsoon rainfall, promoting groundwater recharge with some also storing surface water for year-round use. TBS initiatives, with international aid funding matched by village investment, are located in the rural Arvari (or Arwari), Sarsa and Baghani catchments, lying mostly in Alwar district, north-eastern Rajasthan, the headwaters of which rise from the Aravalli Hills (Figure 1). However, work in adjacent catchments has also restored water resources, with perennial flows returning to five other formerly seasonal rivers - the BhaganiTeldehe, Arvari, Jahajwali, Sarsa and Ruparel - benefitting 250 villages (Jayanti, 2009). Land use in this rural region of Alwar is predominantly agricultural, much of it dependent upon groundwater that has historically been overexploited. Those with resources to pump from the decreasing reserves gain preferential access to the detriment of the majority of people who consequently experience decreasing resource availability and ensuing poverty. 
Figure 1: Location of the Arvari, Sarsa and Baghani catchments in north Rajasthan (from Everard, 2015)

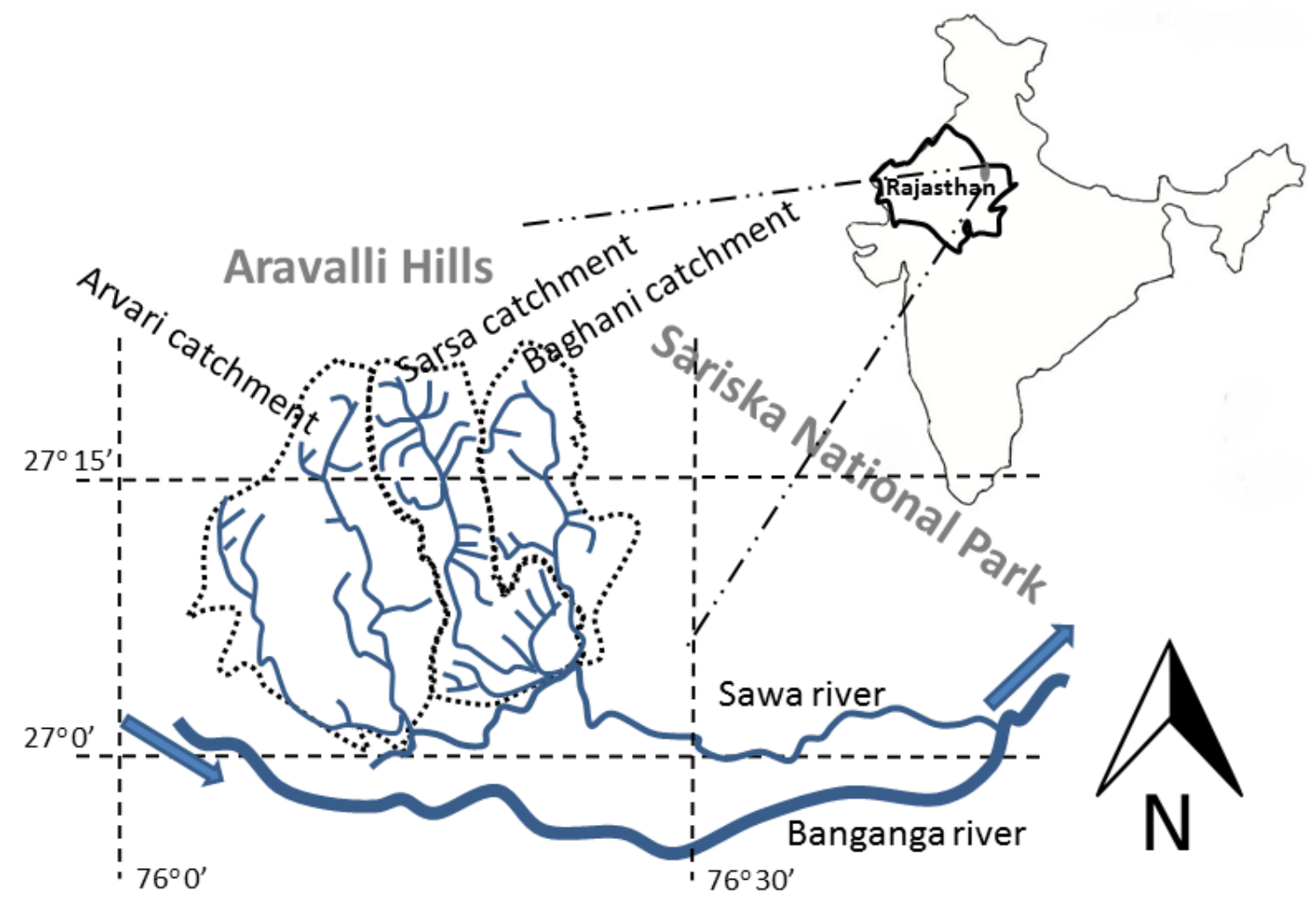

Rathore (2003), Sinha et al. (2013) and Everard (2015) review progress enabled by TBS working in partnership with villages within these and adjacent catchments, rebuilding village- and catchment-scale institutions and reinstituting or innovating an extensive network of WHSs that have collectively regenerated soil moisture and groundwater resources in the formerly desertified landscapes of river valleys. These initiatives have combined in places to reverse the cycle of socio-ecological decline, with quantified increases in groundwater levels, food production, reinstitution of governance structures (particularly 'Gram Sabha': traditional village decision-making bodies with interests in deliberation and decision-making about water management) and the repopulation of villages. This progressive village-by-village regeneration of catchments has not been uniform or entirely free of challenge, particularly from state and central government that often regards it in strict legislative terms as illegal given the centralised control of water management. However, the TBS programme has attracted national and international recognition for contributing to drought resilience and the reversal of pre-intervention cycles of aridification, ecosystem degradation, human impoverishment and rural depopulation.

Everard (2015) examined the characteristics of eleven WHSs and their associated water bodies of varying design, history, size, altitude, purpose and predominant uses in the Arvari, Sarsa and Baghani catchments. He assessed their contributions to restoration of ecosystem service enhancements supporting the livelihoods of local people. Everard (2016) reported upon permanent waterbodies in the three catchments, all of which had been dry outside of monsoon rainfall for as much as 
four decades prior to restoration activities, and assessed their potential to restore traditional medicinal uses, local spiritual and cultural meanings, and other primarily non-utilitarian and non-market ecosystem services associated with catchment regeneration.

Forest cover has increased in areas now managed by communities, the area under forest in Thanagazi tehsil increasing from $8.4 \%$ in $1989 / 90$ to $14.37 \%$ by $1998 / 99$ attributed largely to local reforestation, forest management and grazing controls (Rathore, 2003). There are also increases in the extent of agricultural area enabled by improved soil moisture and accessible groundwater, rising from $42 \%$ in 1989/90 to $54.9 \%$ by $1998 / 99$ (Rathore, 2003), reflecting a locally significant change in land cover. Changes in vegetative cover in response to recharge of groundwater and other interventions are therefore a surrogate both for groundwater levels and a range of linked ecosystem services, including many for which the role of biodiversity is as yet uncertain but is generally perceived as significant (Science for Environment Policy, 2015).

\section{Methodology}

The changes in the local landcover described above should be discernible on satellite images of the area. Research presented in the introduction has established the potential utility of vegetation as a proxy for groundwater expression. We assessed the utility of three RS approaches to identifying the areas where vegetation has been reported as increasing as a result of water harvesting in the case study area. Established multispectral image analysis techniques were used to distinguish vegetation from other land cover types and also to assess plant vigour/condition and stress (Oritz et al., 2011).

The red, Near-infrared (Near-IR, also known as Longwave-IR) and Middle-IR (also referred to as Shortwave-IR) are the most useful parts of the electromagnetic spectrum for vegetation analysis (see Box 2).

\section{Box 2: Key spectral elements of RS vegetation assessment}

- Reflection of red EMR from the Earth's surface is determined primarily by photosynthetic activity (Gates et al., 1965), so measurements across this wavelength range ( 630-700 nanometres) are useful for distinguishing between vegetation and bare soils.

- The infrared (IR) EMR spectrum is over 100 times broader than that of the visible range, and is typically divided into two basic categories: Reflected-IR and Thermal-IR. Reflected-IR is most useful for interpretation of vegetation cover and condition due to the characteristics of leaf structure and reflectance related to the individual roles that different layers of leaves play in leaf function:

- Leaf reflectance at Longwave-IR/Near-IR wavelengths ( 0.7-1.0 to 5 micron wavelength) is primarily affected by the structure of the leaf, which is in turn substantially influenced by moisture content. Many characteristics of leaf structure can contribute to the reflection of Near-Infra Red radiation. Inside 
the leaf, light is scattered at cell interfaces and intercellular air spaces, due to a large change in the refractive index (Slaton et al., 2001). Longer, more cylindrical palisade mesophyll cells propagate the visible wavelengths deeper into the leaf interior, whereas more spherical spongy mesophyll cells tend to scatter the radiation (Vogelmann and Martin, 1993). Near-IR is therefore useful for detecting plant age and stress. For healthy plants, reflection is high as very little energy is absorbed from Near-IR wavelengths. However, as plants experience stress due to the limited availability of water or other causes, the range of wavelengths absorbed at the red end of the visible spectrum has been observed to broaden with greater absorption of longer wavelengths including into the Near-IR, a phenomenon terms 'red shift' (National Learning Network for Remote Sensing, 1999).

o Reflectance of wavelengths of Shortwave-IR/Middle-IR ( 5 to $25-40)$ is more sensitive to moisture, and can therefore be used to monitor vegetation and moisture content (Geospatial Innovation Facility, 2008). This may make it possible to discern different crop species, with differences most evident in the middle of the growing season (Goward, 1985; CCMEO, 2014; Federation of American Scientists, undated). In conjunction with Near-IR reflectance, Middle-IR can be used in the detection of plant stress as the ratio of reflectance of these two bands changes with leaf moisture levels (Federation of American Scientists, undated).

\subsection{Data acquisition and preparation}

The suitability of Landsat data for catchment-scale vegetation analysis underpinning this project is established in the introduction. Remotely sensed images were obtained from data holdings accessible using the United States Geological Survey's EarthExplorer website (United States Geological Survey, undated). The orientation of the three catchments of central interest (the Arvari, Sarsa and Baghani) and adjacent catchments with restored upper reaches (Jahajwali and Ruparel) to this Landsat image are illustrated in Figure 2.

Only images captured between March and May (or the nearest available date) were used as this period is at the crossover between winter and summer and precedes the start of the monsoon period in Rajasthan (the monsoon rains fall from July to September). It was anticipated that this would provide the strongest evidence for vegetation change not associated with potentially confounding seasonal or eventdriven antecedent moisture conditions.

Landsat 5 and the more modern Landsat 8 collect images in different wavelength bands (see Table 2). The spectral bands of primary interest - Red, Near-IR and Middle-IR - are equivalent across the two Landsat missions. Combining images from these two Landsat missions into a single time series for analysis does not introduce significant uncertainty (United States Geological Survey, 2013).

Table 2: Landsat 5 and 8 spectral bands equivalences (Adapted from United States Geological Survey, 2013) 


\begin{tabular}{|c|c|c|c|c|c|}
\hline \multicolumn{3}{|c|}{ Landsat 5 Bands } & \multicolumn{3}{|c|}{ Landsat 8 Bands } \\
\hline \multicolumn{2}{|r|}{ Band } & \multicolumn{2}{|c|}{ Wavelength } & \multicolumn{2}{|l|}{ Band } \\
\hline Band 1 & Blue & $0.45-0.52$ & $0.452-0.512$ & Blue & Band 2 \\
\hline Band 2 & Green & $0.52-0.6$ & $0.53-0.59$ & Green & Band 3 \\
\hline Band 3 & Red & $0.63-0.69$ & $0.64-0.67$ & Red & Band 4 \\
\hline Band 4 & Near-IR & $0.77-0.90$ & $0.85-0.88$ & Near-IR & Band 5 \\
\hline Band 5 & Shortwave IR & $1.55-1.75$ & $1.57-1.65$ & Shortwave-IR1 & Band 6 \\
\hline \multirow{2}{*}{ Band 6} & \multirow{2}{*}{ Thermal IR } & \multirow{2}{*}{$10.4-12.50$} & $10.60-11.19$ & Thermal-IR1 & Band 10 \\
\hline & & & $11.5-12.51$ & Thermal-IR2 & Band 11 \\
\hline Band 7 & Shortwave IR & 2.09-2.35 & 2.11-2.29 & Shortwave-IR2 & Band 7 \\
\hline
\end{tabular}

The United States Geological Survey (USGS) does not hold data recorded by Landsat missions for the first 12 years of TBS-led activities. Suitable, available satellite imagery for the project comprised ten images (1997; 1998; 1999; 2000; 2009; 2010; 2011; 2013; 2014 and 2015).

Figure 2: Locations of the Arvari, Sarsa and Baghani catchments and upper Jahajwali and Ruparel catchments overlaid on Landsat image PATH 147, ROW 41 and showing the area of interest in red. (False colour composite LS5 543: greens represent vegetation and pinks \& browns bare earth.) Dotted lines indicate catchment boundaries. 


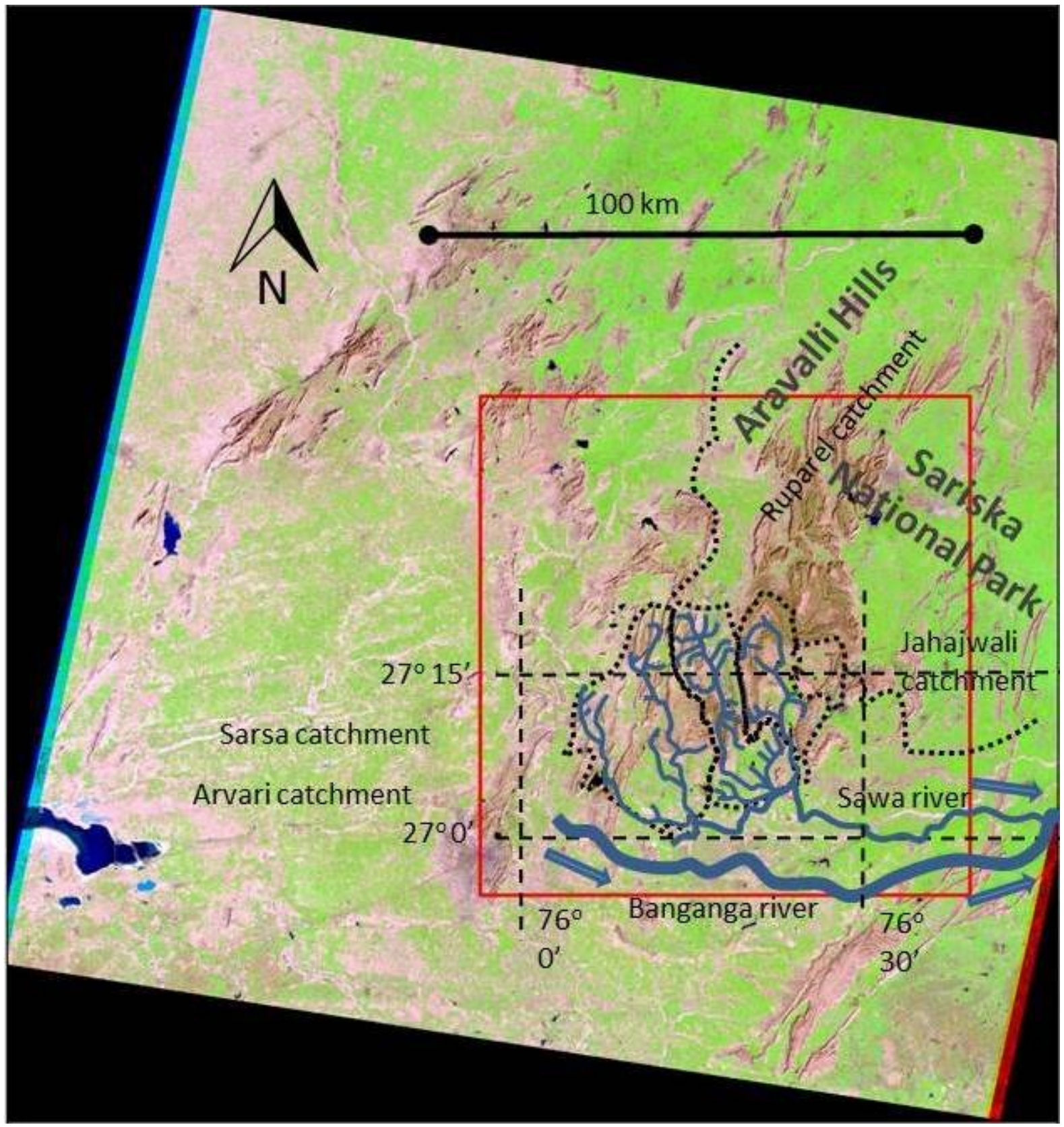

The downloaded files were composited into combined multispectral images. Subset images were created from the composite images, a process that simplifies analysis by selecting the spectral bands relevant to the project (Wallin, 2006), and extracting data based on an area of interest (AOI). The defined AOI was $92 \mathrm{~km}$ (east-west) by $94 \mathrm{~km}$ (north-south) covering $8,648 \mathrm{~km}^{2}$, with the city of Jaipur in the bottom left corner and Alwar in the top right, highlighted in red in Figure 2. The three principal catchments of interest (the Arvari, Sarsa and Baghani) and the upper reaches of adjacent restored catchments (the Jahajwali and Ruparel) are covered by the AOI, which also includes areas to the west and south of these catchments. However, as the five fully or partially restored catchments cover approximately $50 \%$ of the selected $92 \mathrm{~km} \times 94 \mathrm{~km}$ area, and TBS-led restoration has occurred locally in adjacent catchments, it was decided that the area was suitable for time series analysis as it should demonstrate overall change. 


\subsection{Data analysis}

Researchers involved in change detection using remotely sensed data have developed a broad range of methodologies for identifying any changes to the environment (Mas, 1999). For this study, three established, analytical methods were used to interpret the images and assess changes in land cover, plant vigour and moisture stress between 1984 and 2015.

The ISODATA (Iterative Self Organising Data Analysis Technique) classification and change analysis method was used to assess landcover changes between each time step and over the whole period. ISODATA classifies pixels into spectral classes using a clustering algorithm that is applied iteratively until the convergence threshold (change in pixel allocation between iterations is $<95 \%$ ) has been achieved (Xie et al, 2008). Meaningful informational classes are then assigned to the derived spectral classes. In this project, these were disturbed vegetation, irrigated vegetation, bare earth, and water. Once all images had been classified, landcover classes from consecutive dates were compared based on a matrix describing land cover change. For example, an area classified as bare earth in for one observation but as vegetation in the next observation would be classified as vegetation increase in the change analysis. The change matrix used for interpreting changes in land cover between different dates is presented in Table 3 .

Table 3: Change matrix showing the classes used to identity vegetation changes

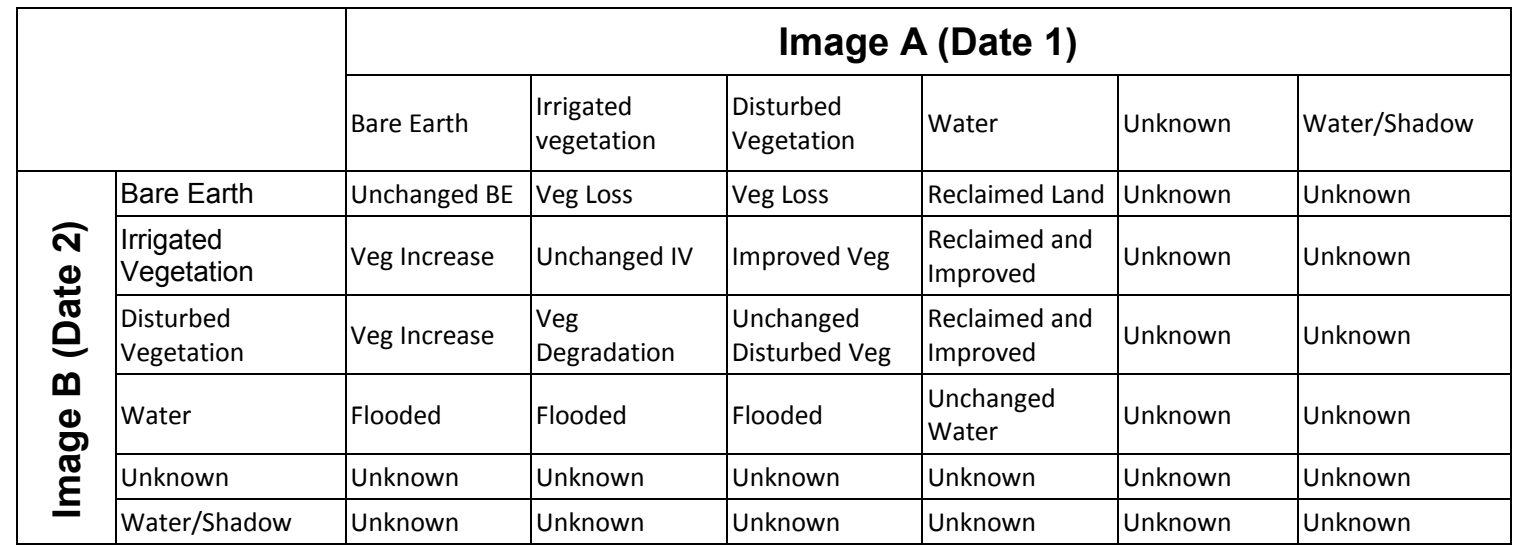

over time

The NDVI (Normalised Difference Vegetation Index) was used to assess vegetation cover and vigour. Vegetation Indices $(\mathrm{VI})$ are mathematical transformations intended to enhance the vegetation signal while minimising solar irradiance and soil background effects, designed to assess the spectral contribution of vegetation to multispectral observations (Jackson and Huete, 1991; Elvidge and Chen, 1995). Vegetation is highly reflective in the Near-IR and highly absorptive in the visible red parts of the spectrum. The ratio between these spectral bands are used as an indicator of the status of vegetation, correlating with the photosynthetic activity of vegetation (Xie et al, 2008). As photosynthetic activity increases, NDVI is expected to increase. Jamali et al (2011) found that vegetation growth indicators such as 
NDVI are highly correlated with soil moisture, making NDVI a good proxy indicator for soil moisture and therefore groundwater in areas with shallow groundwater. The NDVI is calculated using the equation:

$$
\frac{(\text { NearIR }- \text { Red })}{(\text { NearIR }+ \text { Red })}
$$

The Moisture Stress Index (MSI) measure leaf water stress. It is a reflectance measurement that is sensitive to increasing leaf water content, particularly as an indicator of low leaf water content (Ceccato et al., 2001; Hunt and Rock, 1989). As the leaf water content in vegetation increases, the strength of absorption of MiddleIR wavelengths increases; conversely, absorption of Near-IR wavelengths is largely unaffected by changing water content so serves as a reference. In areas where access to groundwater is a key inhibitor of vegetation growth, the MSI would be expected to decrease as leaf water stress decreases, which suggests MSI can serve as a proxy indicator for groundwater availability (Chen and $\mathrm{Hu}, 2004$; Eagleson, 1978; Harris et al., 2005). MSI is calculated using the equation:

$$
\frac{\text { MiddleIR }}{\text { NearIR }}
$$

\section{Results}

Results from the three analytical methods - ISODATA, NDVI and MSI - are presented below. The sensitivity to antecedent moisture conditions of projects assessing groundwater using vegetation as a proxy was highlighted in the introduction. Local climatic variability, over the period of analysis, is examined first as these results inform the interpretation of the analytical results.

\subsection{Local climatic variability}

The weather in Rajasthan over the period of this study is very similar year on year. The hottest month in each year in the time series analysed was May, except for 2014 in which June was the hottest month (Table 4). The highest average temperature per year ranged from a low of 37 Degrees Celsius in May 1997, with the highest being 42 degrees Celsius in May 2010. Many of the years had their driest period of the year in the months just before the months chosen for the images, generally covering a three-month period between November and March (Weather Spark, 2015). Precipitation patterns across the study period (data also from Weather Spark, 2015) are represented in Figure 3.

Table 4: Alwar District annual weather records from Weather Spark (2015)

\begin{tabular}{|l|l|l|l|}
\hline Year & Hottest Month & Highest Temperature & Driest Period \\
\hline 1997 & May & $37^{\circ} \mathrm{C}$ & $1^{\text {st }}$ January $-28^{\text {th }}$ March \\
\hline 1998 & May & $41^{\circ} \mathrm{C}$ & $9^{\text {th }}$ November $-31^{\text {st }}$ December \\
\hline 1999 & May & $40^{\circ} \mathrm{C}$ & $10^{\text {th }}$ February $-8^{\text {th }}$ May \\
\hline 2000 & May & $40^{\circ} \mathrm{C}$ & $1^{\text {st }}$ January $-22^{\text {nd }}$ March \\
\hline
\end{tabular}




\begin{tabular}{|l|l|l|l|}
\hline 2009 & May & $41^{\circ} \mathrm{C}$ & November - December \\
\hline 2010 & May & $42^{\circ} \mathrm{C}$ & $23^{\text {rd }}$ February $-28^{\text {th }}$ April \\
\hline 2011 & May & $40^{\circ} \mathrm{C}$ & September - December \\
\hline 2013 & May & $41^{\circ} \mathrm{C}$ & $9^{\text {th }}$ November $-31^{\text {st }}$ December \\
\hline 2014 & June & $41^{\circ} \mathrm{C}$ & $28^{\text {th }}$ October $-14^{\text {th }}$ December \\
\hline 2015 & May & $41^{\circ} \mathrm{C}$ & \\
\hline
\end{tabular}

Most years had their driest period sometime between November and March (Weather Spark, 2015). Precipitation patterns across the study period (Weather Spark, 2015) are represented in Figure 3.

Figure 3: Total Annual Precipitation in Alwar District (mm) (Weather Spark, 2015)

\section{Alwar District Total Annual Precipitation}

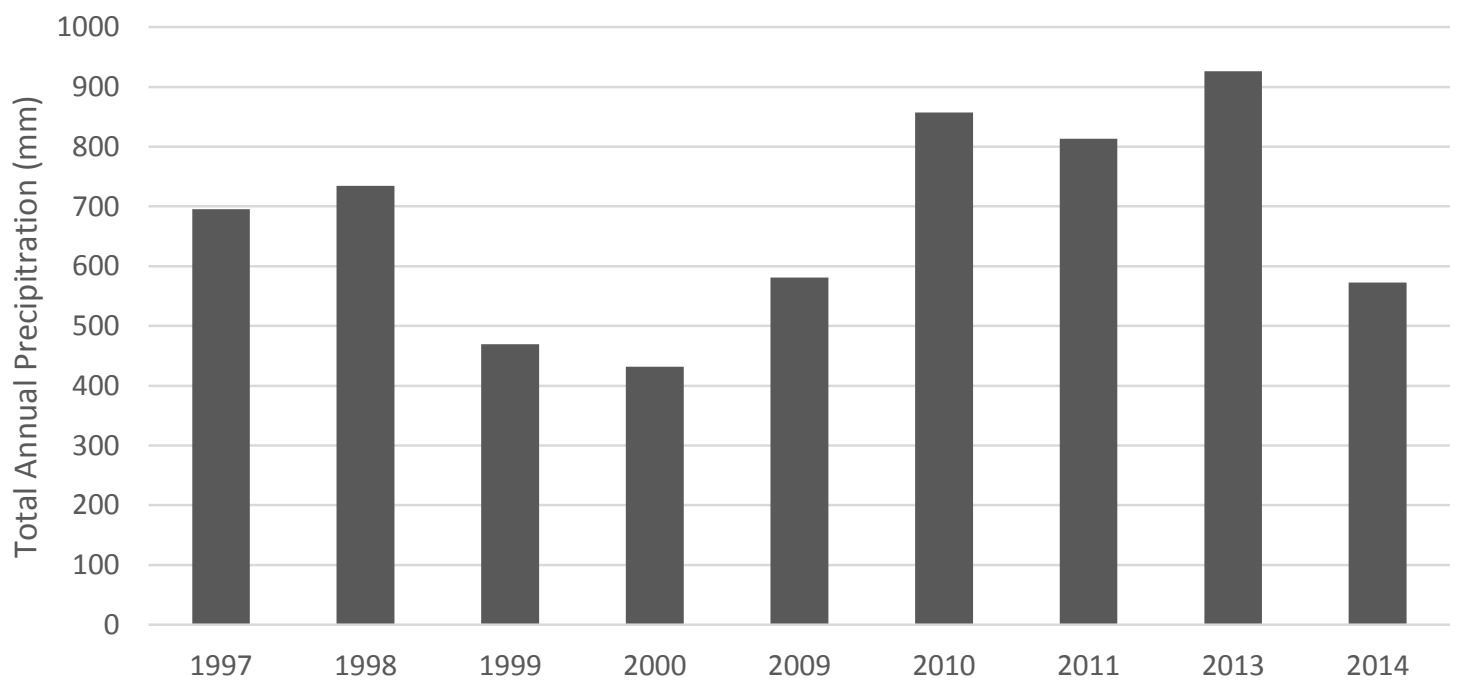

\subsection{The ISODATA classification and change analysis}

Table 5 presents the results from the landcover change analysis and quantifies the change that occurred between image pairs. Increases in a particular change category from one date to the next are highlighted in green and decreases in area are represented in red.

Table 5: Land Cover Area Change $\left(\mathrm{km}^{2}\right)$ and Total Area Change $\left(\mathrm{km}^{2}\right)$. Red indicates a decrease in value whilst green indicates an increase.

\begin{tabular}{|l|l|l|l|l|l|l|l|l|l|}
\hline Year & $\mathbf{9 7 / 9 8}$ & $\mathbf{9 8 / 9 9}$ & $\mathbf{9 9 / 0 0}$ & $\mathbf{0 0 / 0 9}$ & $\mathbf{0 9 / 1 0}$ & $\mathbf{1 0 / 1 1}$ & $\mathbf{1 1 / 1 3}$ & $\mathbf{1 3 / 1 4}$ & $\mathbf{1 4 / 1 5}$ \\
\hline \multirow{2}{*}{ Bare Earth } & \multirow{2}{*}{605.76} & $\mathbf{7 4 5 . 6 0}$ & 881.51 & 874.07 & 898.72 & 802.96 & 562.99 & 521.62 & 519.32 \\
\cline { 3 - 10 } & 139.84 & 135.90 & 7.44 & 24.65 & 95.67 & 239.97 & 41.38 & 2.29 \\
\hline \multirow{2}{*}{$\begin{array}{l}\text { Irrigated } \\
\text { vegetation }\end{array}$} & \multirow{2}{*}{5.18} & 5.95 & 31.25 & 20.25 & 0.97 & 2.49 & 3.24 & 1.89 & 7.07 \\
\hline \multirow{2}{*}{$\begin{array}{l}\text { Disturbed } \\
\text { vegetation }\end{array}$} & \multirow{2}{*}{41.28} & 0.76 & 25.30 & 11.00 & 19.29 & 1.52 & 0.75 & 1.35 & 5.19 \\
\hline \multirow{2}{*}{ Water } & 23.07 & 89.69 & 95.90 & 71.00 & 61.81 & 92.81 & 176.58 & 214.30 \\
\cline { 3 - 10 } & \multirow{2}{*}{0.00} & 2.88 & 71.62 & 6.20 & 24.89 & 9.19 & 31.00 & 83.78 & 37.17 \\
\cline { 3 - 10 } & 2.88 & 1.95 & 0.85 & 0.08 & 0.00 & 0.00 & 0.00 & 0.00 \\
\hline
\end{tabular}




\begin{tabular}{|c|c|c|c|c|c|c|c|c|c|}
\hline Year & $97 / 98$ & $98 / 99$ & $99 / 00$ & $00 / 09$ & $09 / 10$ & $10 / 11$ & $11 / 13$ & $13 / 14$ & $14 / 15$ \\
\hline \multirow{2}{*}{$\begin{array}{l}\text { Vegetation } \\
\text { Increase }\end{array}$} & \multirow{2}{*}{167.97} & 208.42 & 75.55 & 84.34 & 62.38 & 261.20 & 288.40 & 212.70 & 228.02 \\
\hline & & 40.45 & 132.88 & 8.79 & 21.96 & 198.82 & 27.20 & 75.70 & 15.31 \\
\hline \multirow{2}{*}{$\begin{array}{l}\text { Vegetation } \\
\text { Loss }\end{array}$} & \multirow{2}{*}{348.40} & 210.67 & 75.55 & 57.98 & 165.86 & 48.44 & 227.89 & 228.38 & 128.08 \\
\hline & & 137.73 & 135.12 & 17.58 & 107.88 & 117.42 & 179.45 & 0.49 & 100.30 \\
\hline \multirow{2}{*}{$\begin{array}{l}\text { Vegetation } \\
\text { Degradation }\end{array}$} & \multirow{2}{*}{47.42} & 26.94 & 63.06 & 0.74 & 20.86 & 42.45 & 44.01 & 16.76 & 57.81 \\
\hline & & 20.48 & 36.12 & 62.32 & 20.12 & 21.59 & 1.56 & 27.25 & 41.05 \\
\hline \multirow{2}{*}{$\begin{array}{l}\text { Reclaimed } \\
\text { Land }\end{array}$} & \multirow{2}{*}{0.00} & 0.88 & 1.42 & 0.22 & 0.14 & 0.00 & 0.46 & 0.00 & 0.00 \\
\hline & & 0.88 & 0.55 & 1.20 & 0.08 & 0.14 & 0.46 & 0.46 & 0.00 \\
\hline \multirow{2}{*}{$\begin{array}{l}\text { Reclaimed } \\
\text { and } \\
\text { Improved }\end{array}$} & \multirow[b]{2}{*}{0.00} & 0.20 & 0.89 & 0.22 & 0.04 & 0.00 & 0.17 & 0.00 & 0.00 \\
\hline & & 0.20 & 0.69 & 0.67 & 0.18 & 0.04 & 0.17 & 0.17 & 0.00 \\
\hline \multirow{2}{*}{ Flooded } & \multirow{2}{*}{3.95} & 0.37 & 0.10 & 0.10 & 0.00 & 0.62 & 0.00 & 0.00 & 0.00 \\
\hline & & 3.58 & 0.27 & 0.10 & 0.10 & 0.62 & 0.62 & 0.00 & 0.00 \\
\hline
\end{tabular}

On the basis of previously reported observations of increases in agricultural land and forestry by Rathore (2003) as well as those recorded by Sinha et al. (2013) and Everard (2015), bare earth extent would be expected to decrease as areas used for agricultural production and tree cover increased. Vegetation increase (bare earth transitioning to vegetative cover) did indeed rise as expected over the time series. Between 1997 and 2015, bare earth decreased with $288.4 \mathrm{~km}^{2}$ becoming vegetated. The largest annual vegetation increase occurred between 2010 and 2011 when a total of $261.2 \mathrm{~km}^{2}$ became vegetated (an increase of $198.8 \mathrm{~km}^{2}$ between years). This could be attributed to the later rains in 2010 and the early rains in 2011 recorded by Weather Spark (2015). Vegetation increased again by $27.2 \mathrm{~km}^{2}$, rising to $288.4 \mathrm{~km}^{2}$ by $2011 / 2013$, a further increase that could again be accounted for by the increased amount of precipitation that fell in January and February $2013(117 \mathrm{~mm}$ fell over the two months, more than all the previous years combined over the same period: Water Resources Rajasthan, 2015, and Weather Spark, 2015). By comparison, a total area of $183.1 \mathrm{~km}^{2}$ became degraded between 1997 and 2015, changing to bare earth from vegetation. $483 \mathrm{~km}^{2}$ of bare earth remained unchanged between 1997 and 2015 , though the area of land covered by bare earth fluctuated throughout the time series with a peak of $898.7 \mathrm{~km}^{2}$ in $2009 / 2010$ and a minimum area of $519.3 \mathrm{~km}^{2}$ recorded in 2014/2015. Overall, these ISODATA results are consistent with the vegetation increase reported previously, indicating an increase in groundwater supporting its growth and its potential to provide a range of enhanced ecosystem services.

Total area of irrigated vegetation remained unchanged at $17.7 \mathrm{~km}^{2}$ between 1997 and 2015. However, there was significant year-on-year variability throughout this time series. The highest amount of annual unchanged irrigated vegetation detected in $1999 / 2000\left(31.2 \mathrm{~km}^{2}\right)$ represented an increase of $25.30 \mathrm{~km}^{2}$ on the previous year, but there was a substantial subsequent decline of $30.29 \mathrm{~km}^{2}$ so that left only $0.96 \mathrm{~km}^{2}$ remaining irrigated vegetation in 2009/2010. This sharp decline could be accounted for by the land being used for different purposes, or more likely by the weather as 4 of the 5 months prior to the data being captured were extremely dry (2009 experienced its driest period between November and December whilst 2010 had its driest period between February and March). Subsequently, the area of irrigated vegetation steadily rose to $7.1 \mathrm{~km}^{2}$ by $2014 / 2015$. The amount of unchanged disturbed vegetation varied throughout the 1997-2015 time series, but followed no pattern. Overall, $165 \mathrm{~km}^{2}$ of disturbed vegetation remained unchanged between 1997 and 2015. 
Although some water features were detectable, these were all large water bodies such as lakes and reservoirs. It was not possible to determine trends in extent in open surface water bodies due to limitations imposed by the spatial resolution $(30 \mathrm{~m})$ and spectral resolution of the Landsat data within this survey, so the study could not confirm observations recorded by Sinha et al. (2013) and Everard (2015).

However, all of these analyses have to be interpreted with caution as spectral confusion between some areas of water and shadows cast by the low-lying sun in Landsat 8 images leaves a large area $\left(42.16 \mathrm{~km}^{2}\right)$ classified as 'unknown'.

\subsection{NDVI comparison of plant photosynthetic activity}

Increases in groundwater levels reported by Rathore (2003 and 2005), Sinha et al. (2013) and Everard (2015) would be expected to result in an increase in farmed and natural vegetation cover. Therefore, NDVI extent and value would be expected to increase over the time series of this study. However, evidence presented in Table 6 indicates that NDVI decreased by up to $20 \%$ over an area of $116.4 \mathrm{~km}^{2}$ between 1997 and 2015, with only $9.7 \mathrm{~km}^{2}$ showing an increase between 0 and $20 \%$ in NDVI.

Table 6: Area $\left(\mathrm{km}^{2}\right)$ of NDVI change at $20 \%$ threshold

\begin{tabular}{|l|l|l|l|l|l|l|l|l|l|l|}
\hline NDVI & $97 / 98$ & $98 / 99$ & $99 / 00$ & $00 / 09$ & $09 / 10$ & $10 / 11$ & $11 / 13$ & $13 / 14$ & $14 / 15$ & $97 / 15$ \\
\hline $\begin{array}{l}20 \% \\
\text { Increase }\end{array}$ & 3.776 & 80.268 & 4.505 & 6.335 & 0.023 & 197.446 & 0.000 & 0.242 & 170.729 & 9.750 \\
\hline $\begin{array}{l}20 \% \\
\text { decrease }\end{array}$ & 164.869 & 0.710 & 14.846 & 1.173 & 87.636 & 0.000 & 148.990 & 7.410 & 0.049 & 116.454 \\
\hline
\end{tabular}

However, inter-annual fluctuation in NDVI across the time sequence was significant. The largest single change happened between 2010 and 2011, when NDVI increased by $20 \%$ in $197.4 \mathrm{~km}^{2}$ (NDVI values in $20 \%$ of pixels increased in comparison to the previous year) with no area showing a decrease of $20 \%$. The largest decrease in NDVI happened between $1997 / 1998$, where $164.9 \mathrm{~km}^{2}$ showed a $20 \%$ decrease, although $3.7 \mathrm{~km}^{2}$ did also show a $20 \%$ increase that year. These years of interannual increase in NDVI follow years after increased amounts of rainfall, as illustrated in Figure 4, consistent with a relationship between NDVI and precipitation observed by Jamali et al. (2011).

Figure 4: Area Changes in NDVI $\left(\mathrm{km}^{2}\right)$ and Total Annual Precipitation 


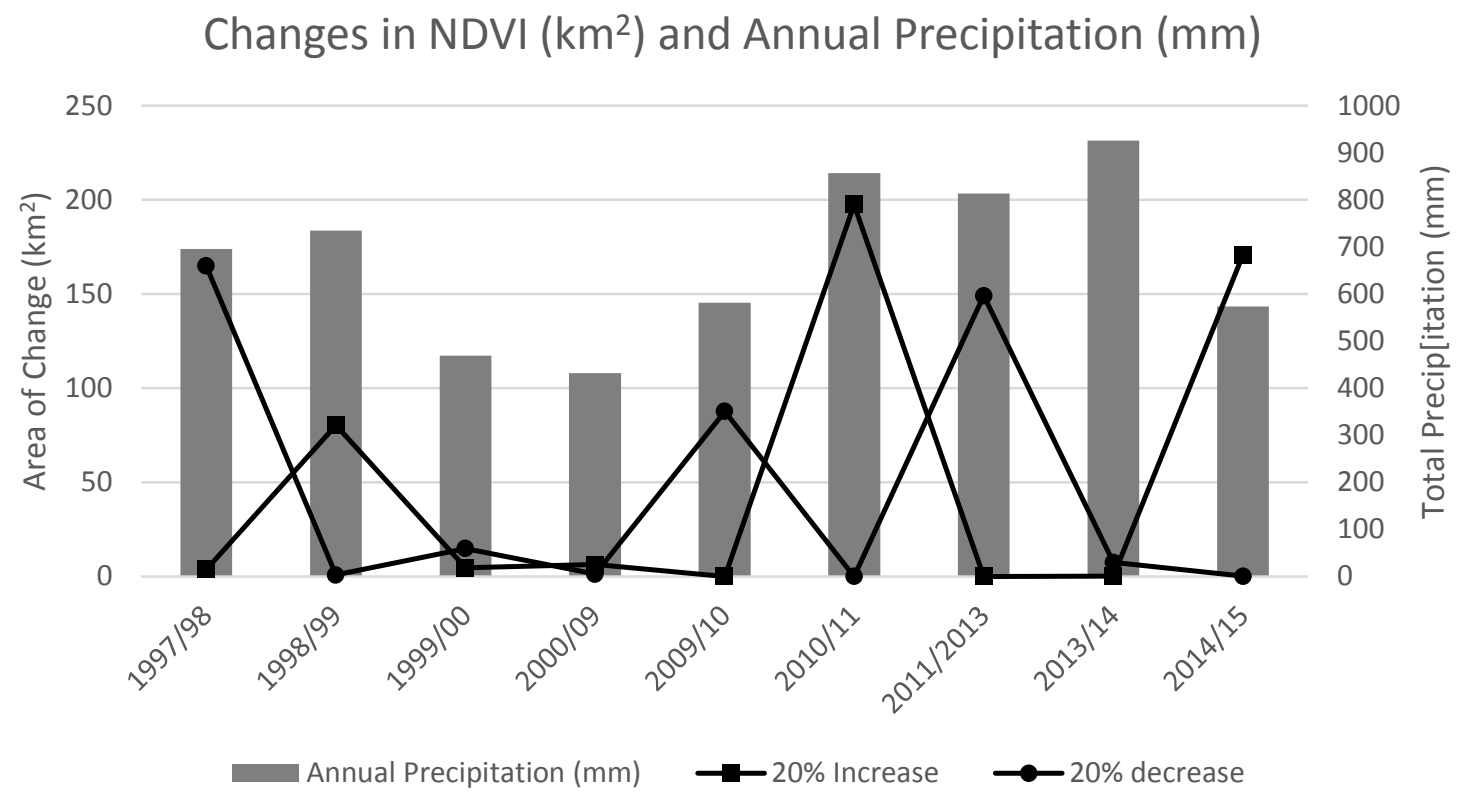

\subsection{MSI comparison of plant water stress}

It would be expected that, as groundwater levels increased, leaf moisture would increase and therefore MSI would decrease. Data presented in Table 7 demonstrate that MSI decreased by at least $20 \%$ over an area of $132.3 \mathrm{~km}^{2}$ between 1997 and 2015 , whilst only $41.5 \mathrm{~km}^{2}$ showed an increase of $20 \%$ over the same period. Across this time series, 1999/2000 experienced the smallest area of inter-annual decrease $\left(0.0009 \mathrm{~km}^{2}\right)$ whilst $1998 / 1999$ saw the largest inter-annual decrease $\left(295.6 \mathrm{~km}^{2}\right)$, with areas of $0.6 \mathrm{~km}^{2}$ and $26.4 \mathrm{~km}^{2}$ (20\% decreases) in 1997/1998 and 2014/2015 respectively. There were also some incidences where MSI had increased by at least $20 \%$, although these covered very small areas $\left(2.2 \mathrm{~km}^{2}\right.$ in $1997 / 1998,0.06 \mathrm{~km}^{2}$ in $1998 / 1999,1 \mathrm{~km}^{2}$ in $2000 / 2009,0.03 \mathrm{~km}^{2}$ in $2009 / 2010$ and $2.6 \mathrm{~km}^{2}$ in $2014 / 2015$, with the largest increase of at least $20 \%$ between $2013 / 2014$ of $121.9 \mathrm{~km}^{2}$ ).

Table 7: Area $\left(\mathrm{km}^{2}\right)$ of MSI change at $20 \%$ threshold

\begin{tabular}{|l|l|l|l|l|l|l|l|l|l|l|}
\hline $\begin{array}{l}\text { MSI } \\
\text { change }\end{array}$ & $97 / 98$ & $98 / 99$ & $99 / 00$ & $00 / 09$ & $09 / 10$ & $10 / 11$ & $11 / 13$ & $13 / 14$ & $14 / 15$ & $97 / 15$ \\
\hline $\begin{array}{l}20 \% \\
\text { increase }\end{array}$ & 2.222 & 0.061 & 0.000 & 1.022 & 0.033 & 0.000 & 0.000 & 121.951 & 2.594 & 41.479 \\
\hline $\begin{array}{l}20 \% \\
\text { decrease }\end{array}$ & 0.621 & 295.623 & 0.001 & 0.000 & 0.000 & 0.000 & 0.000 & 0.000 & 26.430 & 132.246 \\
\hline
\end{tabular}

The largest inter-annual MSI decrease in 1998/1999, expected if groundwater is recharged, could be explained by the high levels of precipitation seen in 1998. The second-highest decrease (26.430) between 2014 and 2015 also followed increased precipitation. However, although precipitation was on an increasing trend in 2009 and 2010 , a small area $\left(0.03 \mathrm{~km}^{2}\right)$ experienced a $20 \%$ increase in MSI between these years with no decreases.

It should also be added that the years that saw the most dramatic decreases in MSI (1998/1999 and 2014/2015) were preceded by increased precipitation (see Figure 
5). These years also experienced some of the largest increases in NDVI. Since NDVI increases with plant growth, these increases in NDVI would be expected as indicator of increasing groundwater and soil moisture. This would be caused by capillary rise, meaning MSI should decrease (Harris et al, 2005 and Eagleson, 1978).

Figure 5: Area Changes in $\mathrm{MSI}\left(\mathrm{km}^{2}\right)$ and Total Annual Precipitation

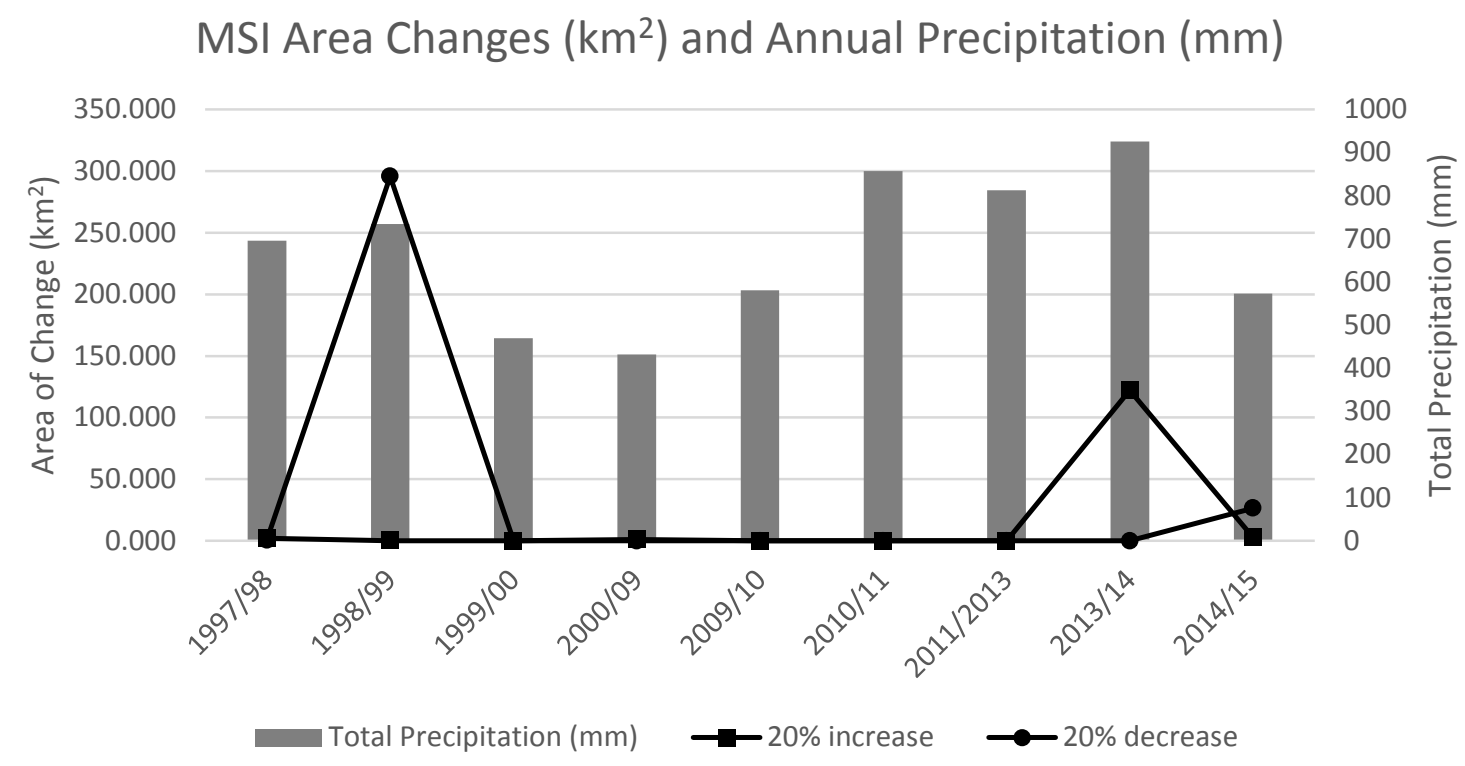

\section{Discussion}

This study has investigated whether remote sensing technology can be used to assess the success of community-level groundwater recharge initiatives in catchments in Alwar District, Rajasthan (India) by considering RS-derived trends in vegetative cover and health in the light of observed socio-ecological outcomes reported by Rathore (2003), Sinha et al. (2013) and Everard (2015).

The ISODATA classification and change analysis detected an increase in vegetation cover between 1997 and 2015, although the method was unsuccessful in detecting evidence of river rejuvenation due to the spatial and spectral resolution of data from Landsat missions. The remotely sensed increase in vegetation cover of $254.8 \mathrm{~km}^{2}$ is generally consistent with catchment regeneration reported by Rathore (2003), Sinha et al. (2013) and Everard (2015). Between 1997 and 2015, the area of bare earth dropped steadily, consistent with Rathore's (2003 and 2005) observation that land area used for agriculture and forestry increased between 1989 and 1998 with an anticipated increasing trend.

It was not possible to determine trends in the extent of surface water based on our research due to the spatial and spectral limitations of Landsat data. Although some water features were detectable, these were all large water bodies such as lakes and reservoirs. There are two explanations for the inability detect smaller rivers in the study area. If the water level in rivers was very low it would not have influenced the 
spectral response of the associated pixels and the rivers would be undetectable. Sediment in the rivers, due both to the nature of the catchment and uses such as stock watering, may further complicate differentiating surface water from bare earth. The only detected features enabling inference of the presence of narrow rivers were surrounding, irrigated vegetation areas running along the banks. These features converge with larger rivers further downstream, outside of the case study area, suggesting a topo-hydrological link.

Results from the analysis of NDVI and MSI were less clear. NDVI would be expected to increase and MSI to decrease between 1997 and 2015. However, analyses in this study found that NDVI decreased by at least $20 \%$ over an area of $116.4 \mathrm{~km}^{2}$ with only $9.7 \mathrm{~km}^{2}$ showing a $20 \%$ increase, though there was a general decrease in MSI consistent with general expectations. This may be partially explained by considering that a $20 \%$ change in either index does not necessarily imply an increase or loss of vegetation cover, but a change in vigour or stress. A change analysis with a lower threshold than $20 \%$, or a series of increasing thresholds, may reveal a stronger pattern. Significant inter-annual fluctuations in NDVI and MSI appeared to follow the amount of antecedent rainfall, at least for the largest increases of NDVI and decreases of MSI, consistent with a vegetative response to increasing soil moisture and groundwater levels.

The results may support an inference of the impact of WHSs in the case study area, based on vegetation fluxes, but it is not unequivocal. However, it appears that the ISODATA-derived landcover change analysis does support reported revegetation over the analytical time period. Year-on-year, rainfall-related fluctuations in NDVI and MSI may suggest a correlation between groundwater and vegetative extent and condition, but the limitations of spatial and spectral resolution in the available Landsat datasets meant that it was not possible to isolate this from climatic drivers.

Uncertainties in the analytical outcomes are exacerbated by an incomplete temporal dataset, as RS data for the initial 12 years of WHS activities in the case study area were not available. In some images, a low sun angle resulted in large areas of shadows eliminating the ability to evaluate landcover change in these areas. Despite being the best available data, the Landsat spatial resolution was too coarse to detect some elements of interest such as small, shallow streams. The ISODATA algorithm as applied to Landsat imagery failed to discern differences between some land cover classes.

Equivocal though the conclusions drawn from analysis of limited data from Landsat missions may be, our research nevertheless proves the principle of an RS-based approach supporting the monitoring of indicators of likely ecosystem service changes over broad landscapes where other forms of consistent measurement of ecosystem service change may be difficult or unaffordable. It also highlights the type of research necessary to provide a useful management support tool, based on finerresolution satellite images (the ESA Sentinel 2 mission with substantially improved spatial and spectral resolution may now meet some of this need) and improved analytical methods. This type of RS-based analysis of proxy indicators may offer the best prospects of assessing long-term trends and the efficacy of restoration measures, as a surrogate for linked, water-dependent ecosystem services and their potential to support livelihoods. It can also constitute a tool informing policy 
formulation, addressing extensive landscapes that are otherwise hard and/or expensive to monitor by other means. This in turn can assist with identification of policy responses best promoting sustainable water resource regeneration and management, providing indications of both the efficacy and the suitability of measures supporting rather than undermining community-based institutional and physical land and water management practices that have a long heritage in India. Broad-scale insights into trends in water and vegetation extent and condition in the landscape, of the kind possible through indicators derived from remote sensing data, offer significant potential for better-informed, more far-sighted policy and management decision-making that better empowers local action within an overall policy framework. These indicators can serve as a proxy for a wider suite of ecosystem services essential for human wellbeing and ecosystem resilience. Where the efficacy of restorative measures can be demonstrated by RS and other techniques, this can provide valuable input to reform India's currently fragmented water management policy environment.

Promotion of a transition from state-imposed regulation towards an enabling framework that is synergistic with diverse local culturally and environmentally appropriate solutions is important to the realisation of sustainable water management, as high-level policy has to be flexible to account for substantial heterogeneity in both natural and human landscapes. This flexibility is essential if policies are to be effectively targeted, accepted and effective in supporting the ecosystem service outcomes that people value, many of them mediated by water flows through landscapes, rather than merely treating water as a commodity divorced from its myriad environmental functions.

\section{Conclusions}

Analysis of remotely sensed imagery can provide a basis for assessment of trends in vegetation extent, vigour and stress over broad spatial scales and across time series. However, our analysis of available, medium resolution remotely sensed data to corroborate reported natural and farmed landscape regeneration in Alwar District as a result of WHSs produced equivocal results. Landcover change analysis generally correlated with reported observations in vegetation cover and condition between 1997 and 2015, whereas results NDVI and MSI analysis drew less clear trends over the time series but calculated inter-annual fluctuations were strongly correlated with rainfall in the preceding year. This makes is difficult to attribute landcover change to the WHSs implemented in the region, and confirms the difficulties identified by Becker's (2006) review.

Nevertheless, this research shows initial promise, highlighting that further research based on finer-resolution satellite images and improved analytical methods may serve as a useful management support tool. Issues related to resolution may be resolved by improved imagery. The ESA Sentinel 2 data, with spatial and spectral resolution improvements, may be of particular interest in this regard. As a recently launched RS platform, it cannot provide data for longitudinal studies such as this. However, a seasonally based intra-annual analysis, comparing the case study area with a similar area without WHSs would be a suitable test of the potential of these new imagery products. 
In the absence of actual groundwater depth data, projects such as this unavoidably have to rely on proxy data, which will inevitably be contestable. This suggests that collecting information about groundwater depth in the case study area may be particularly expedient in developing a case in support of WHSs. It will also help make empirical links with the enhancement of a range of linked ecosystem services, for which NVDI and other similar indices serve as indicators.

Methodological improvements to the implemented analyses may result in more robust evidence of the value of WHSs than we were able to produce. Exploring the utility of other landcover derivation techniques, in particular, maximum likelihood supervised classification techniques based on in-field observation of training areas may improve the utility of RS in this context. The particularly equivocal NDVI and MSI results may be a result of the $20 \%$ threshold specification for change analysis. Modifying this, and relating the observed change to the initial vegetation condition represented by the index value, may result in a more nuanced assessment or plant vigour and stress.

Even with the noted limitations of the implemented methods, the RS techniques implemented are potentially valuable for detecting trends across broad landscapes, and could inform more insightful policy and management decisions that recognise the important roles of localised, community-based water and land management in addressing policy goals relating to sustainable water management. Such overviews of water and land cover trends enabled through interpretation of remote sensing data can better inform decision-making, empowering local action attuned to the heterogeneity of both natural and human landscapes and recognising the many ecosystem service outcomes mediated by water rather than merely treating it as a commodity.

\section{References}

2030 Water Resources Group. (2009). Charting Our Water Future: Economic frameworks to inform decision-making. 2030 Water Resources Group, McKinsey.

Becker, M.W. (2006). Potential for Satellite Remote Sensing of Ground Water. Ground Water, 44(2), pp.306-318.

CCMEO. (2014). Tutorial: Fundamentals of Remote Sensing. Canada Centre for Mapping and Earth Observation. [Online] (http://www.nrcan.gc.ca/earthsciences/geomatics/satellite-imagery-air-photos/satellite-imageryproducts/educational-resources/9309, accessed $6^{\text {th }}$ February 2016.)

Ceccato, P., Flasse, S., Tarantola, S., Jacquemoud, S. and Gregoire, J-M. (2001) Detecting vegetation leaf water content using reflectance in the optical domain. Remote Sensing of Environment, 77, pp.22-33.

Central Ground Water Board. (2006). Dynamic Ground Water Resources of India. Central Ground Water Board, New Delhi. 
Central Water Commission. (2013). Water and Related Statistics. [Online] (http://www.cwc.nic.in/main/downloads/Water\%20and\%20Related\%20Statistics2013.pdf, accessed $6^{\text {th }}$ February 2016.)

Chen, X. and Hu, Q. (2004) Groundwater Influences on soil moisture and surface evaporation. Journal of Hydrology, 297(1-4), pp.285-300.

Chenworth, J. (2008). Minimum water requirement for social and economic development. Desalination, 229, pp.254-256.

Chinnasamy, P., Maheshwari, B. and Prathapar, S. (2015). Understanding Groundwater Storage Changes and Recharge in Rajasthan, India through Remote Sensing. Water, 7(10), pp.5547-5565. doi:10.3390/w7105547

Eagleson, P.S. (1978). Climate, Soil and Vegetation: A Simplified Model of Soil Moisture Movement in the Liquid Phase. Water Resources Research, 14(5), pp.722730.

Edet, E.A., Okereke, S.C., Teme, C.S., and Esu, O.E. (1998). Application of remotesensing data to groundwater exploration: A case study of the Cross River State, southeastern Nigeria. Hydrogeology Journal, 6(3), pp.394-404.

doi.org/10.1007/s100400050162.

Elvidge, C.D. and Chen, Z. (1995) A Soil Adjusted Vegetation Index (SAVI). Remote Sensing of Environment, 25, pp.295-309.

Everard, M. (2013). The Hydropolitics of Dams: Engineering or Ecosystems? Zed Books, London.

Everard, M. (2015) Community-based groundwater and ecosystem restoration in semi-arid north Rajasthan (1): Socio-economic progress and lessons for groundwater-dependent areas. Ecosystem Services, 16, pp.125-135.

Everard, M. (2016). Community-based groundwater and ecosystem restoration in semi-arid north Rajasthan (2): reviving cultural meaning and value. Ecosystem Services.

Federation of American Scientists. (undated). Supervised Classification. Federation of American Scientists. [Online]. (http://fas.org/irp/imint/docs/rst/Sect1/Sect1 17.html, accessed $6^{\text {th }}$ February 2016.)

Federation of American Scientists. (undated). Vegetation Applications: Agriculture, Forestry and Ecology. General Principles for Recognizing Vegetation. Federation of American Scientists. [Online]. (http://fas.org/irp/imint/docs/rst/Sect3/Sect3 1.html, accessed $6^{\text {th }}$ February 2016.)

Food and Agriculture Organisation. (2010). Deep Wells and Prudence: Towards Pragmatic Action for Addressing Groundwater Overexploitation in India. Food and Agriculture Organisation of the United Nations. [Online] 
(http://www.fao.org/nr/water/apfarms/upload/PDF/world bank rep.pdf, accessed $6^{\text {th }}$ February 2016.)

Food and Agriculture Organisation. (2015). Aquastat: India. Food and Agriculture Organisation of the United Nations. [Online] (http://www.fao.org/nr/water/aquastat/countries regions/ind/index.stm, accessed $6^{\text {th }}$ February 2016.)

Gates, D.M., Keegan, H.J., Schleter, J.C and Weidner, V.R. (1965) Spectral Properties of Plants. Applied Optics, 4, pp.11-20.

George, K.V., Pillai, K.V. and Mathew, J. (2015). Studies on Water Resource Management: Approaches and Strategies. International Journal of Advanced Research, 3(11), pp.781-791.

Geospatial Innovation Facility. (2008). Landsat Spectral Band Information. [Online] (http://gif.berkeley.edu/documents/Landsat\%20Band\%20Information.pdf, accessed $6^{\text {th }}$ February 2016.)

Glenn, E.P., Huete, A.R., Nagler, P.L and Nelson, S.G. (2008). Relationship between Remotely Sensed Vegetation Indices, Canopy Attributes and Plant Physiological Processes: What Vegetation Indices Can and Cannot Tell Us About the Landscape. Sensors, 8(4), pp.2136-2160.

Government of India. (2007). Report of the expert group on "Groundwater management and ownership" submitted to Planning Commission, September 2007. Government of India, Planning Commission, New Delhi.

Goward, S. (1985) shortwave infrared detection of vegetation. Advances in Space Research, 5(5), pp.41-50

Harris, A., Bryant, R.G. and Baird, A.J. (2005). Detecting near-surface moisture stress in Sphagnum spp. Remote Sensing of Environment, 97, pp.371-381.

Heilman, J.L., and D.G. Moore. 1982. Evaluating depth to shallow groundwater using Heat-Capacity Mapping Mission (HCMM) data. Photogrammetric Engineering and Remote Sensing 48(12) pp.1903-1906

Hoffmann, J. (2005). The future of satellite remote sensing in hydrology. Hydrogeology Journal, 13(1), pp.247-250.

Hunt Jr, E. and Rock, B. (1989) Detection of Changes in Leaf Water Content using Near- and Middle-Infrared Reflectances. Remote Sensing of Environment, 33, pp. 43-54.

Jackson, R.D. and Huete, A.R. (1991). Interpreting Vegetation Indices. Preventative Veterinary Medicine, 11, pp.185-200.

Jayanti, G. (2009). 25 years of evolution: restoring life and hope to a barren land. Tarun Bharat Sangh, Alwar. 
Jin, X., Wan, L., Zhan, Y., Xue, Z., and Yin, Y. (2007). A Study of the Relationship Between Vegetation Growth and Groundwater in the Yinchuan Plain. Earth Science Frontiers, 14(3) pp.197-203. http://dx.doi.org/10.1016/S1872-5791(07)60026-8.

Lv, J., Wang, X.., Zhou, Y., Qian, K., Wan, L., Eamus, D. and Tao, Z. (2013), Groundwater-dependent distribution of vegetation in Hailiutu River catchment, a semi-arid region in China. Ecohydrology, 6, pp.142-149. doi:10.1002/eco.1254.

Jamali, S., Seaquist, J., Ardo, J. and Eklundh, L. (2011). Investigating temporal relationships between rainfall, soil moisture and MODIS-derived NDVI and EVI for six sites in Africa. $34^{\text {th }}$ International Symposium on Remote Sensing of Environment. [Online] (http://lup.lub.lu.se/record/4194995, accessed $6^{\text {th }}$ February 2016.)

Kidwell, H. (2015). Recharging India's Aquifers. [Online] (http://www.waterworld.com/articles/wwi/print/volume-25/issue-2/editorialfocus/groundwater-treatment/recharging-india-s.html, accessed $6^{\text {th }}$ February 2016.)

Köppen, W. and Wegener, A. (1924). Die Klimate der Geologischen Vorzeit. Berlin, Stuttgart: Gebr. Borntraeger.

Landsat Science. (undated). The Worldwide Reference System. Landsat Science. (http://landsat.gsfc.nasa.gov/?p=3231, accessed 10th February 2016.)

Mas J.F. (1999). Monitoring land-cover changes: a comparison of change detection techniques. International Journal of Remote Sensing, 20(1), pp.139-152.

Meijerink, A.M.J. (1996). Remote sensing applications to hydrology: Groundwater. Hydrological Sciences Journal, 41(4), pp.549-561.

NASA. (2015). About: Landsat Then and Now. National Aeronautics and Space Administration. [Online] (http://landsat.gsfc.nasa.gov/?page id=2/landsat5.html, accessed $6^{\text {th }}$ February 2016 .)

National Learning Network for Remote Sensing. (1999). Spectral Properties of Vegetation. [Online]

(http://www.nln.geos.ed.ac.uk/courses/english/ars/a2200/a2200008.htm, accessed $6^{\text {th }}$ February 2016.)

National Oceanic and Atmospheric Administration. (2014). What is Remote Sensing? [Online] (http://oceanservice.noaa.gov/facts/remotesensing.html, accessed $6^{\text {th }}$ February 2016.)

Natural Resources Canada. (2013). Spectral Resolution. Natural Resources Canada. [Online] (http://www.nrcan.gc.ca/earth-sciences/geomatics/satelliteimagery-air-photos/satellite-imagery-products/educational-resources/9393, accessed $6^{\text {th }}$ February 2016.)

Natural Resources Canada. (2014). Temporal Resolution. Natural Resources Canada. [Online] (http://www.nrcan.gc.ca/earth-sciences/geomatics/satellite- 
imagery-air-photos/satellite-imagery-products/educational-resources/9365, accessed $6^{\text {th }}$ February 2016.)

NRCAN. (2012). Spatial Resolution, Pixel Size and Scale. Natural Resources Canada. (http://www.nrcan.gc.ca/earth-sciences/geomatics/satellite-imagery-airphotos/satellite-imagery-products/educational-resources/9407, accessed $6^{\text {th }}$ February 2016.)

Oritz, B., Shaw. J. and Fulton, J. (2011) Basics of Crop Sensing. [Online] (https://sites.aces.edu/group/crops/precisionag/Publications/Basics\%20of\%20Crops \%20Sensing\%20-\%20Ext\%20Pub\%20ANR-1398.pdf, accessed $6^{\text {th }}$ February 2016 .)

Pérez Hoyos, I.C., Krakauer, N.Y., Khanbilvardi, R. and Armstrong, R.A. (2016). A Review of Advances in the Identification and Characterization of Groundwater Dependent Ecosystems Using Geospatial Technologies. Geosciences, 6(17), 20pp. [online] doi:10.3390/geosciences6020017.

Postel, S. (2015). India's Food Security Threatened by Groundwater Depletion. National Geographic, $3^{\text {rd }}$ February 2015. [Online] http://voices.nationalgeographic.com/2015/02/03/indias-food-security-threatened-bygroundwater-depletion/, accessed $6^{\text {th }}$ February 2016.)

Pu, R., Gong, P., Yong, T., Miao, X., Carruthers, R.I. and Anderson, G.L. (2008). Using Classification and NDVI Differencing Methods for Monitoring Sparse Vegetation Coverage: A Case Study of Salt cedar in Nevada, USA. International Journal of Remote Sensing, 29(14), pp.3987-4011.

Rathore, M.S. (2003). Community based management of groundwater resources: a case study of Alwar River Basin. Institute of Development Studies, Jaipur.

Rathore, M.S. (2005). Groundwater exploration and augmentation efforts in Rajasthan: a review. Institute of Development Studies, Jaipur.

Rosenberry, D.O., R.G. Striegl, and D.C. Hudson. (2000). Plants as indicators of focused ground water discharge to a northern Minnesota lake. Ground Water, 38(2), pp. 296-303.

Satellite Imaging Corporation. (2015). Satellite Remote Sensing Systems. [Online] (http://www.satimagingcorp.com/services/resources/characterization-of-satelliteremote-sensing-systems/, accessed $6^{\text {th }}$ February 2016.)

Science for Environment Policy. (2015). Ecosystem Services and the Environment. In-depth Report 11 produced for the European Commission, DG Environment by the Science Communication Unit, University of the West of England, Bristol. (http://ec.europa.eu/environment/integration/research/newsalert/pdf/ecosystem servi ces biodiversity IR11 en.pdf, accessed $6^{\text {th }}$ February 2016.)

Sharma, B.K., Kulshreshtha, S. and Sharma, S. (2013). Historical, sociocultural, and mythological aspects of faunal conservation in Rajasthan. In: Sharma, B.K., 
Kulshreshtha, S. AND Rahmani, A.R. (eds.) Faunal Heritage of Rajasthan, India: general Background and Ecology of Vertebrates, Volume 1. Springer: New York.

Singh, D.K. and Singh, A.K. (2002). Groundwater Situation in India: Problems and Perspective International Journal of Water Resources Development, 18, pp.563-580.

Sharma, K.D., Singh, S., Singh, N. and Bohra, D.N. (1989). Satellite remote sensing for detecting the temporal changes in the grazing lands. Journal of the Indian Society of Remote Sensing, 17(4), pp.55-59.

Shenbagaraj, N., Mani, N.D. and Muthukumar, M. (2014). Isodata Classification Technique to Assess the Shoreline Changes of Kolachel to Kayalpattanam Coast. International Journal of Engineering Research \& Technology, 3(4), pp.311-314.

Singh, D.K. and Singh A.K. (2002). Groundwater Situation in India: Problems and Perspective. International Journal of Water Resources Development, 18, pp.563580.

Singh, R. (2009). Community Driven Approach for Artificial Recharge -TBS Experience. Bhu-Jal News Quarterly Journal, 24(4), pp.53-56.

Sinha J, Sinha MK and Adapa UR 2013. Flow - River Rejuvenation in India: Impact of Tarun Bharat Sangh's Work. SIDA Decentralised Evaluation 2013:28. Swedish International Development Cooperation Agency, Stockholm.

Slaton, M.R., Hunt Jr., R.E. and Smith, W.K. (2001). Estimating Near Infra-Red reflectance from leaf structural Characteristics. American Journal of Botany, 88(2), pp.278-284.

Tóth, J. (1963). A theoretical analysis of groundwater flow in small drainage basins. Journal of Geophysical Research, 68, pp.4795-4812.

United States Geological Survey. (2013). Frequently Asked Questions about the Landsat Missions. (http://landsat.usgs.gov/best spectral bands to use.php, accessed $6^{\text {th }}$ February 2016.)

United Nations. (2003). Water for people, water for life. World Water Assessment Programme, United Nations General Assembly.

United Nations. (2015). Water for Life Decade. United Nations. [Online] (http://www.un.org/waterforlifedecade/water and sustainable development.shtml, accessed $6^{\text {th }}$ February 2016.)

United Nations. (2015). Resolution adopted by the General Assembly on 25 September 2015: 70/1. Transforming our world: the 2030 Agenda for Sustainable Development. United Nations General Assembly, New York. (http://www.un.org/en/ga/search/view doc.asp?symbol=A/RES/70/1\&Lang=E, accessed $6^{\text {th }}$ February 2016.) 
Water Resources Rajasthan. (2015). Rainfall Data. Government of Rajasthan. [Online]

(http://waterresources.rajasthan.gov.in/Daily Rainfall Data/Rainfall Index.htm, accessed $6^{\text {th }}$ February 2016.)

USAID. (2015). Water and Development Strategy. USAID. [Online] (https://www.usaid.gov/what-we-do/water-and-sanitation/water-and-developmentstrategy, accessed $6^{\text {th }}$ February 2016.)

United States Geological Survey. (undated). EarthExplorer. United States Geological Survey. (http://earthexplorer.usgs.gov/, accessed $6^{\text {th }}$ February 2016.)

Vogelmann, T.C. and Martin, G. (1993). The functional significance of palisade tissue: penetration of directional versus diffuse light. Plant, Cell and Environment, 16, pp.65-72.

Wallin, D. (2006). Creating a Subset of a Larger ERDAS Imagine File. [Online] (http://www.wwu.edu/huxley/spatial/tut/ERDAS subset.htm, accessed $6^{\text {th }}$ February 2016.)

Weather Spark. (2015). Historical Weather for India. Weather Spark. [Online] (https://weatherspark.com/history/stations/India, accessed $6^{\text {th }}$ February 2016.)

World Health Organisation. (2014). Progress on Drinking Water and Sanitation 2014 Update. World Health Organisation. [Online] (http://apps.who.int/iris/bitstream/10665/112727/1/9789241507240 eng.pdf, accessed $6^{\text {th }}$ February 2016.)

Xie, Y., Sha, Z. and Yu, M. (2008). Remote sensing Imagery in vegetation mapping: a review. Journal of Plant Ecology, 1(1), pp.9-23. 